\title{
Effect of Phosphorus and Sulphur Fertilization on Yield and Quality of Wheat (Triticum aestivum L.)
}

\author{
Deen Dayal Bairwa*, J. M. Modhvadia and Bhawani Singh Prajapat \\ Department of Agronomy, College of Agriculture, Junagadh Agricultural University, \\ Junagadh, (Gujarat), India \\ *Corresponding author
}

\section{A B S T R A C T}

\begin{tabular}{l} 
Ke y w o r d s \\
$\begin{array}{l}\text { Yield, Quality, } \\
\text { Phosphorus, } \\
\text { Sulphur, Interaction } \\
\text { effect, Wheat }\end{array}$ \\
\hline Article Info \\
\hline $\begin{array}{l}\text { Accepted: } \\
\text { 07 March } 2020 \\
\text { Available Online: } \\
\text { 10 April } 2020\end{array}$ \\
\hline
\end{tabular}

\begin{abstract}
A field experiment was conducted on calcareous clayey soil at Junagadh (Gujarat) during rabi season, 2015-16 to study the effect of phosphorus and sulphur fertilization on yield and quality of Wheat (Triticum aestivum L.). The experimental results revealed that application of $90 \mathrm{~kg} \mathrm{P}_{2} \mathrm{O}_{5}$ ha $^{-1}\left(\mathrm{P}_{3}\right)$ recorded maximum No. of tillers (89.9), No. of grain spike $^{-1}(44.8)$, test weight $(46.18 \mathrm{~g})$, grain yield $\left(4451 \mathrm{~kg} \mathrm{ha}^{-1}\right)$, straw yield $\left(6886 \mathrm{~kg} \mathrm{ha}^{-1}\right)$ and protein content in grain (12.69\%) which was found at par with $\mathrm{P}_{2}\left(60 \mathrm{~kg} \mathrm{P}_{2} \mathrm{O}_{5}\right.$ ha $\left.^{-1}\right)$. Application of $40 \mathrm{~kg} \mathrm{~S} \mathrm{ha}^{-1}$ was found at par $20 \mathrm{~kg} \mathrm{~S} \mathrm{ha}^{-1}$ and significantly increased No. of tillers (88.6), No. of grain spike ${ }^{-1}(43.1)$, test weight $(45.78 \mathrm{~g})$, grain yield $(4354 \mathrm{~kg}$ $\left.\mathrm{ha}^{-1}\right)$, straw yield $\left(6809 \mathrm{~kg} \mathrm{ha}^{-1}\right)$ and protein content in grain $(12.08 \%)$. Combined application of $90 \mathrm{~kg} \mathrm{P}_{2} \mathrm{O}_{5} \mathrm{ha}^{-1}+40 \mathrm{~kg} \mathrm{~S}^{-1}\left(\mathrm{P}_{3} \mathrm{~S}_{2}\right)$ recorded significantly maximum number of grains spike ${ }^{-1}(47.33)$, test weight of $(46.77 \mathrm{~g})$ and grain yield (4937 $\left.\mathrm{kg} \mathrm{ha}^{-1}\right)$ than the control $\left(\mathrm{P}_{0} \mathrm{~S}_{0}\right)$.
\end{abstract}

\section{Introduction}

Globally, demand for wheat by the year 2020 is forecasted at around 950 million tonns per year. This target will be achieved only, if global wheat production is increased approximately by 2.5 per cent per annum (Patel et al., 2015) ${ }^{1}$. In India, it occupied an area of 300 lakh ha and production of 93.50 million tonnes and productivity of 3117 $\mathrm{kg} \mathrm{ha}{ }^{-1}$. India will have to produce 105 million tonnes of wheat by 2020. In Gujarat, wheat is grown on an area of 10.24 lakh ha with total production of 29.44 lakh tons and productivity $2803 \mathrm{~kg} \mathrm{ha}^{-1}$ (Anon., 2013) ${ }^{2}$. In
India, The highest productivity of wheat is recorded in Punjab, whereas Gujarat stands $6^{\text {th }}$ rank with productivity of $2.8 \mathrm{t} \mathrm{ha}^{-1}$ (Anon. 2013) ${ }^{2}$. Thus, today wheat has become not only the staple food of a large population of India but has also become the rays of hope for wardening off extensive starvation. In Saurashtra region of Gujarat, most soil is medium black calcareous soil, having poor $\mathrm{N}$ and S status. Maneuvering the application of different fertilizers could increase the productivity of the wheat crop and the protein content. Comparatively lower productivity in Gujarat is due to several constraints like lack of irrigation facilities, imbalanced use of 
fertilizers and lack of knowledge of modern agro techniques such as suitable genotypes, proper sowing time, seed rate, spacing, weed control, fertilization, plant protection measures etc.

Phosphorus is the second most essential plant nutrient which plays a major role for achieving the maximum crop production. It plays a vital role in several physiological processes viz. photosynthesis, respiration, energy storage and cell division/ enlargement. It is also an important structural component of many biochemicals viz. nucleic acid (DNA and RNA enzymes and co-enzymes) and also stimulates root growth and associated with early maturity of crops. Sulphur is another one of the essential nutrient in all plant nutrients and component of amino acids which are the building block of protein. In the cereal crops, sulphur contain in the ranges from $0.16-0.20 \%$.

The critical limit of sulphur in plant is 0.20$0.25 \%$, where crop show sulphur deficiency. Element sulphur is not available to plants. Element sulphur is oxidized in the form sulphate by soil micro-organisms, make available to the plant. Therefore, keeping these considerations in view, this experiment was undertaken.

\section{Materials and Methods}

The present study was conducted throughout rabi season of 2015-16 at the College Farm, College of Agriculture, Junagadh Agricultural University, Junagadh (Gujarat) to study the Effect of Phosphorus and Sulphur Fertilization on Yield and Qualtiy of Wheat (Triticum aestivum L.). The soil of the experimental plot was Silty Loam in texture and slightly alkaline in reaction with $\mathrm{pH} 8.10$ and EC of $0.36 \mathrm{dS} \mathrm{m}$. The soil was low in available nitrogen $\left(242 \mathrm{~kg} \mathrm{ha}^{-1}\right)$, medium in available phosphorus $\left(39.20 \mathrm{~kg} \mathrm{ha}^{-1}\right)$, high in available potash $\left(292 \mathrm{~kg} \mathrm{ha}^{-1}\right)$ and medium in available sulphur (19.05 ppm).

The experiment was conducted in factorial randomized block design with total 12 treatment combination consisting of 4 levels of phosphorus viz., $0.00 \mathrm{~kg} \mathrm{ha}^{-1}\left(\mathrm{P}_{0}\right), 30.00 \mathrm{~kg}$ $\mathrm{ha}^{-1}\left(\mathrm{P}_{1}\right), 60.00 \mathrm{~kg} \mathrm{ha}^{-1}\left(\mathrm{P}_{2}\right)$ and $90.00 \mathrm{~kg} \mathrm{ha}^{-1}$ $\left(\mathrm{P}_{3}\right)$ and 3 levels of sulphur $(0.00,20.00$ and $40.00 \mathrm{~kg} \mathrm{ha}^{-1}$ as $\mathrm{S}_{0}, \mathrm{~S}_{1}$ and $\mathrm{S}_{2}$, respectively).

These treatments were replicated three times. Recommended dose of nitrogen, phosphorus and potassium $\left(\mathrm{N}: \mathrm{P}_{2} \mathrm{O}_{5}: \mathrm{K}_{2} \mathrm{O} @ 120: 60: 60 \mathrm{~kg}\right.$ $\mathrm{ha}^{-1}$ in the form of urea $(46 \% \mathrm{~N})$, diammonium phosphate $\left(46 \% \mathrm{P}_{2} \mathrm{O}_{5}\right.$ and $\left.18 \% \mathrm{~N}\right)$ and muriate of potash $\left(60 \% \mathrm{~K}_{2} \mathrm{O}\right), 60 \mathrm{~kg} \mathrm{ha}^{-1}$ nitrogen and full dose of $\mathrm{P}$ (as per treatments) and $\mathrm{K}$ were applied as basal application and rest $60 \mathrm{~kg} \mathrm{ha}^{-1}$ nitrogen was applied at 30 days after sowing. Sulphur in form of Cosavet (90\% S) was applied as per treatments. The protein and nitrogen content in seeds was worked out by using the following analysis method.

\section{Protein content (\%)}

Protein content in grain was determined by multiplying nitrogen content in grain (\%) by a factor 6.25 (Gassi et al., 1973) ${ }^{3}$.

Protein content $(\%)=\mathrm{N}$ content in grain $(\%)$ $\times 6.25$

\section{Nitrogen content in grain}

Estimation of nitrogen content in grain was carried out by micro Kjeldahl's method as described by A. O. A. C. (Anon., 1965) ${ }^{4}$. The uptake of nitrogen by grain was calculated with formula as given below:

\begin{tabular}{|c|c|c|}
\hline Nitrogen & & $\begin{array}{l}\text { Nitrogen content in grain }(\%) \\
\mathrm{x} \text { Grain yield }\left(\mathrm{kg} \mathrm{ha}^{-1}\right)\end{array}$ \\
\hline $\begin{array}{l}\text { uptake by grain } \\
\left(\mathrm{kg} \mathrm{ha}^{-1}\right)\end{array}$ & $=$ & 100 \\
\hline
\end{tabular}




\section{Results and Discussion}

\section{Effect of phosphorus}

The results furnished that different treatment of phosphorus significant influenced on yield and quality of wheat (Table 1). Application of $90 \mathrm{~kg} \mathrm{P} \mathrm{P}_{2} \mathrm{O}_{5}$ ha $^{-1}\left(\mathrm{P}_{3}\right)$ recorded significantly maximum number of tillers (89.9), number of grains spike $^{-1}$ (44.8), test weight of (46.18 g), grain yield of $\left(4451 \mathrm{~kg} \mathrm{ha}^{-1}\right)$, straw yield $\left(6886 \mathrm{~kg} \mathrm{ha}^{-1}\right)$ and protein content of (12.69 $\%$ ) which was remained at par with $\mathrm{P}_{2}$ (i.e. 60 $\mathrm{kg} \mathrm{P}_{2} \mathrm{O}_{5} \mathrm{ha}^{-1}$ ).

Yield attributes and yield viz., increased number of tillers by $10.67 \%$ and $8.21 \%$ number of grains spike ${ }^{-1}$ by $12.89 \%$ and 8.12 $\%$, test weight by $9.59 \%$ and $5.21 \%$, grain yield by $26.41 \%$ and $13.44 \%$, straw yield by $14.47 \%$ and $8.86 \%$ and protein content 18.83 $\%$ and $12.66 \%$ respectively by $90 \mathrm{~kg} \mathrm{P}_{2} \mathrm{O}_{5}$
$\mathrm{ha}^{-1}\left(\mathrm{P}_{3}\right)$ and $60 \mathrm{~kg} \mathrm{P}_{2} \mathrm{O}_{5} \mathrm{ha}^{-1}\left(\mathrm{P}_{2}\right)$ under the control $\left(\mathrm{P}_{0}\right)$. Increase in yield attributes and yield with increase in the level of phosphorus is due to one of the important function of phosphorus is to increase the number of tillers in cereals. Phosphorus plays an important role in enzymatic reaction and metabolism which ultimately increase the total and effective tillers. Phosphorus is the important constituent and co-enzymes which are important for photosynthesis and protein synthesis. More protein synthesis in presence of phosphorus and formation of some stable phospho- protein compounds is responsible for higher protein content with phosphorus application; secondly the increase in protein content under these levels was going to higher $\mathrm{N}$ uptake by grain which resulted in higher protein content. These results confirm the earlier finding of Khan et al., (2007) ${ }^{5}$, Gaur and Singh (2010) ${ }^{6}$, Hussain et al., (2011) ${ }^{7}$ and Arshad et al., (2016) ${ }^{8}$.

Table.1 Effect of phosphorus and sulphur on yield and quality of wheat

\begin{tabular}{|c|c|c|c|c|c|c|}
\hline Treatment & $\begin{array}{l}\text { Number of tillers } \\
\text { (Meter row } \\
\text { length) }\end{array}$ & $\begin{array}{c}\text { Number } \\
\text { of grains } \\
\text { spike }^{-1}\end{array}$ & $\begin{array}{c}\text { Test weight } \\
\text { (g) }\end{array}$ & $\begin{array}{l}\text { Grain yield } \\
\quad\left(\mathrm{kg} \mathrm{ha}^{-1}\right)\end{array}$ & $\begin{array}{l}\text { Straw yield } \\
\left(\mathrm{kg} \mathrm{ha}^{-1}\right)\end{array}$ & $\begin{array}{c}\text { Protein content } \\
(\%)\end{array}$ \\
\hline \multicolumn{7}{|c|}{ Phosphorus $\left(\mathrm{P}_{2} \mathrm{O}_{5} \mathrm{~kg} \mathrm{ha}^{-1}\right)$} \\
\hline $\mathbf{P}_{0^{-}} \mathbf{0}$ & 81.2 & 39.7 & 42.14 & 3521 & 6016 & 10.62 \\
\hline$P_{1}-30$ & 83.0 & 40.8 & 43.44 & 3623 & 6242 & 11.12 \\
\hline$P_{2^{-}} 60$ & 87.9 & 42.9 & 44.33 & 3994 & 6549 & 11.97 \\
\hline $\mathbf{P}_{3^{-}} \mathbf{9 0}$ & 89.9 & 44.8 & 46.18 & 4451 & 6886 & 12.69 \\
\hline S.Em. \pm & 2.32 & 1.13 & 0.76 & 163 & 216 & 0.30 \\
\hline C.D. at $5 \%$ & 6.82 & 3.33 & 2.23 & 478 & 635 & 0.88 \\
\hline \multicolumn{7}{|c|}{ Sulphur (S kg ha-1) } \\
\hline$S_{0}-0$ & 81.1 & 39.9 & 42.44 & 3398 & 6127 & 11.03 \\
\hline$S_{1}-20$ & 86.8 & 43.0 & 43.85 & 3940 & 6334 & 11.64 \\
\hline$S_{2^{-}}-40$ & 88.6 & 43.1 & 45.78 & 4354 & 6809 & 12.08 \\
\hline S.Em. \pm & 2.01 & 0.98 & 0.66 & 141 & 187 & 0.26 \\
\hline C.D. at $5 \%$ & 5.91 & 2.88 & 1.93 & 414 & 550 & 0.77 \\
\hline \multicolumn{7}{|c|}{ Interaction $(\mathbf{P} \times \mathbf{S})$} \\
\hline S.Em. \pm & 4.03 & 1.96 & 1.32 & 282 & 375 & 0.52 \\
\hline C.D. at $5 \%$ & NS & 5.76 & 3.86 & 828 & NS & NS \\
\hline C.V. \% & 8.16 & 8.09 & 5.18 & 12.55 & 10.11 & 7.80 \\
\hline
\end{tabular}


Table.2 Interaction effect of phosphorus and sulphur on number of grains spike ${ }^{-1}$

\begin{tabular}{|c|c|c|c|}
\hline \multirow{2}{*}{$\begin{array}{c}\text { Levels of } \\
\text { phosphorus }\end{array}$} & \multicolumn{3}{|c|}{ Levels of sulphur } \\
\hline & $S_{0}-0$ & $S_{1}=20$ & $S_{2}-40$ \\
\hline $\mathbf{P}_{0^{-}} \mathbf{0}$ & 39.33 & 41.33 & 38.33 \\
\hline$P_{1}=30$ & 42.67 & 39.33 & 40.33 \\
\hline$P_{2}-60$ & 37.33 & 44.67 & 46.67 \\
\hline$P_{3^{-}} 90$ & 40.00 & 47.00 & 47.33 \\
\hline S.Em. \pm & & 1.96 & \\
\hline C.D. at $5 \%$ & & 5.76 & \\
\hline
\end{tabular}

Table.3 Interaction effect of phosphorus and sulphur on test weight

\begin{tabular}{|c|c|c|c|}
\hline \multirow{2}{*}{$\begin{array}{l}\text { Levels of } \\
\text { phosphorus }\end{array}$} & \multicolumn{3}{|c|}{ Levels of sulphur } \\
\hline & $S_{0^{-}} \mathbf{O}$ & $S_{1}-20$ & $S_{2}-40$ \\
\hline $\mathbf{P}_{0^{-}} \mathbf{0}$ & 38.08 & 42.47 & 45.87 \\
\hline $\mathbf{P}_{1-30}$ & 40.40 & 43.62 & 46.30 \\
\hline$P_{2}-60$ & 45.60 & 43.20 & 44.20 \\
\hline$P_{3}-90$ & 45.67 & 46.10 & 46.77 \\
\hline S.Em. \pm & & 1.32 & \\
\hline C.D. at $5 \%$ & & 3.86 & \\
\hline
\end{tabular}

Table.4 Interaction effect of phosphorus and sulphur on grain yield

\begin{tabular}{|c|c|c|c|}
\hline \multirow{2}{*}{$\begin{array}{l}\text { Levels of } \\
\text { phosphorus }\end{array}$} & \multicolumn{3}{|c|}{ Levels of sulphur } \\
\hline & $S_{0}-0$ & $S_{1}-20$ & $S_{2}-40$ \\
\hline $\mathbf{P}_{0}=0$ & 2711 & 3574 & 4276 \\
\hline $\mathbf{P}_{1}-\mathbf{3 0}$ & 3287 & 3160 & 4422 \\
\hline$P_{2}-60$ & 3881 & 4321 & 3779 \\
\hline$P_{3^{-}} 90$ & 3711 & 4703 & 4937 \\
\hline S.Em. \pm & & 282 & \\
\hline C.D. at $5 \%$ & & 828 & \\
\hline
\end{tabular}

\section{Effect of sulphur}

The results showed that different levels of sulphur manifested their significant influence on yield and quality of wheat (Table 1). Significantly maximum number of tillers (88.6), number of grains spike $^{-1}$ (43.1) test weight of $(45.78 \mathrm{~g})$, grain yield of $(4354 \mathrm{~kg}$ $\left.\mathrm{ha}^{-1}\right)$, straw yield $\left(6809 \mathrm{~kg} \mathrm{ha}^{-1}\right)$ and protein content of $(12.08 \%)$ were registered with application of $40 \mathrm{~kg} \mathrm{~S} h a^{-1}\left(\mathrm{~S}_{2}\right)$ and it was found at par $20 \mathrm{~kg} \mathrm{~S} \mathrm{ha}^{-1}\left(\mathrm{~S}_{1}\right)$. Significantly increased number of tillers by $9.14 \%$ and $6.88 \%$, number of grains spike ${ }^{-1}$ by $8.37 \%$ and $8.16 \%$, test weight by $7.89 \%$ and 3.32 $\%$, grain yield by $28.14 \%$ and $15.96 \%$, straw yield by $11.12 \%$ and $3.38 \%$ and protein content by $9.44 \%$ and $5.51 \%$ respectively by

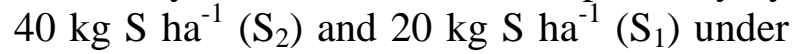
the control $\left(\mathrm{P}_{0}\right)$. It might be due to the fact that sulphur is a part of essential amino acids which helps in chlorophyll formation, photosynthetic process and activation of enzyme and seed formation. The greater 
photosynthetic activity and chlorophyll synthesis due to fertilization seemed to have promoted vegetative growth. Sulphur supply affects the utilization of the available nitrogen by crop. Since, nitrogen and sulphur are required for the synthesis of proteins; the ratio of total $\mathrm{N}$ to total $\mathrm{S}$ in plant tissue has a direct bearing on protein synthesis. These result are in close conformity with those reported by Orman and Ok (2012), Singh and Bhadoria (2013), Khan et al., (2015), Kharub and Dhillon (2007), Palsaniva and Ahlawat (2007), Manchanda et al., (2011), Singh and Singh (2016) and Podlesna and Pietrzak (2008) in wheat crop.

\section{Interaction Effect of Phosphorus and Sulphur}

The perusal of data presented in (Table 2, 3 and 4) clearly indicate that Interaction effect of between phosphorus and sulphur were found significant with respect to number of grain spike $^{-1}$, test weight and grain yield. Combined Application of $90 \mathrm{~kg} \mathrm{P}_{2} \mathrm{O}_{5} \mathrm{ha}^{-1}+$ $40 \mathrm{~kg} \mathrm{~S}$ ha $^{-1}\left(\mathrm{P}_{3} \mathrm{~S}_{2}\right)$ recorded maximum number of grain spike ${ }^{-1}$ (47.33) and remained at par with $\mathrm{P}_{3} \mathrm{~S}_{1}, \mathrm{P}_{2} \mathrm{~S}_{2}, \mathrm{P}_{2} \mathrm{~S}_{1}$ and $\mathrm{P}_{1} \mathrm{~S}_{0}$. Significantly the minimum number of grains spike $^{-1}$ (38.33) was recorded under treatment combination $\mathrm{P}_{0} \mathrm{~S}_{2}$. Wheat crop was fertilized with $90 \mathrm{~kg} \mathrm{P}_{2} \mathrm{O}_{5} \mathrm{ha}^{-1}+40 \mathrm{~kg} \mathrm{~S}^{-1}\left(\mathrm{P}_{3} \mathrm{~S}_{2}\right)$ produced bold size grain which recorded maximum test weight of $46.77 \mathrm{~g}$ and it was remained statistically on same bar with treatment combinations of $\mathrm{P}_{3} \mathrm{~S}_{1}, \mathrm{P}_{3} \mathrm{~S}_{0}, \mathrm{P}_{2} \mathrm{~S}_{2}$, $\mathrm{P}_{2} \mathrm{~S}_{1}, \mathrm{P}_{2} \mathrm{~S}_{0}, \mathrm{P}_{1} \mathrm{~S}_{2}, \mathrm{P}_{1} \mathrm{~S}_{1}$ and $\mathrm{P}_{0} \mathrm{~S}_{2}$. Significantly minimum test weight of $(38.08 \mathrm{~g})$ was noted under treatment combination of $\mathrm{P}_{0} \mathrm{~S}_{0}$. Significantly the maximum grain yield (4937 $\mathrm{kg} \mathrm{ha}^{-1}$ ) was produced when wheat crop was fertilized with $90 \mathrm{~kg} \mathrm{P}_{2} \mathrm{O}_{5} \mathrm{ha}^{-1}+40 \mathrm{~kg} \mathrm{~S}^{-1}$ $\left(\mathrm{P}_{3} \mathrm{~S}_{2}\right)$ which was remained statistically at par with treatment combinations of $\mathrm{P}_{3} \mathrm{~S}_{1}, \mathrm{P}_{2} \mathrm{~S}_{1}$, $\mathrm{P}_{1} \mathrm{~S}_{2}$, and $\mathrm{P}_{0} \mathrm{~S}_{2}$. Significantly the lower grain yield of $\left(2711 \mathrm{~kg} \mathrm{ha}^{-1}\right)$ was recorded under control treatment $\left(\mathrm{P}_{0} \mathrm{~S}_{0}\right)$. It might be because phosphorus and sulphur are being absorbed as anions and have a synergistic effect on each other. The results collaborate with the findings of Marok and Dev (1980), Randhawa and Arora (2000), Islam et al., (2006) and Abdallah et al., (2013) in wheat crop.

In conclusion based on the results of one year field investigation, it seem quite logical is conclude that application of phosphorus @90 $\mathrm{kg} \mathrm{ha}{ }^{-1}$ and application of sulphur @ 40 $\mathrm{kg} \mathrm{ha}^{-1}$ recorded the highest No. of tillers, No. of grain spike ${ }^{-1}$, test weight, grain yield, straw yield and protein content in grain which were significantly superior over their respective lower levels.

\section{References}

Patel J. B., Ukani, J. D., Babariya, C. A. and Ramani, P. S. 2015. Characterization of wheat varieties (Triticum spp.) through seed morphology. Journal of Applied and Natural Science, 8 (1): 464-468.

Anonymous. 2013. Progress Report 2012-2013. Directorate of Wheat Research, Karnal, India pp.6.

Gassi, S., Tikoo, J. L. and Banerjee, S. K. 1973. Changes in protein and methionine content in the maturing seeds of legumes. Seed Research, 1: 104-106.

Anonymous. 1965. Official Methods of Analysis. 8th ed. Association of official Agric. Chemists, (A. O. A. C.) Washington, D. C.

Khan, R., Gurmani, A. R., Gurmani, A. H. and Zia, M. S. 2007. Effect of phosphorus application on wheat and rice yield under wheat- rice system. Sarhad J. Agric. 23(4): 851-856.

Gaur, M. and Singh, V. 2010. Effect of phosphorus and boron on yield and uptake of nutrients by wheat. Annals of Agriculture Research, 31(3\&4): 119-122.

Hussain, N., Khan, M. B., Ahmad, R., Ali, M. A., Ahmed, N. and Saeed, S. 2011. Physiochemical traits, productivity and net 
return of wheat as affected by phosphorus and zinc requirements under arid climates. Pak. J. Bot., 43(2): 991-1002.

Arshad, M., Adnan, M., Ahmed, S., Khan, A. K., Ali, I., Ali, M., Ali, A., Khan, A., Kamal, M. A., Gul, F. and Khan, M. A. 2016. Integrated effect of phosphorus and zinc on wheat crop. American-Eurasian J. Agric. \& Environ. Sci., 16 (3): 455-459.

Orman, S. and Ok, H. 2012. Effects of sulphur and zinc applications on growth and nutrition of bread wheat in calcareous clay loam soil. African J. of Biotech., 11(13): 3080-3086.

Singh, H. and Bhadoria, H. S. 2013. Response of wheat to Azotobacter, nitrogen and sulphur application in an alluvial soil. Annals of Agriculture Research, 34(4): 337-341.

Khan, R. M., Subhanullah, A., Hussain, Z. and Muhammad, Z. 2015. Influence of sulphur and nitrogen on growth, yield and quality of wheat crop grown in Peshawar region of Pakistan. J. Glob. Innov. Agric. Soc. Sci., 3(4): 124-129.

Kharub, A. S. and Dhillon, O. P. 2007. Effect of sulphur application on productivity and quality of wheat (Triticum aestivum). Indian Journal of Agricultural Science, 77(1): 18-20.

Palsaniva, D. R. and Ahlawat, P. S. 2007. Crop productivity, quality and nutrient uptake of pigeonpea (Cajanus cajan) - wheat (Triticum aestivum) cropping system as influenced by sulphur management. Indian Journal of Agricultural Science, 77(10): 660-690.
Manchanda, J. S., Benipal, D. S. and Bhatti, D. S. 2011.Yield and sulphur nutrition of paddy-wheat cropping system as influenced by sources and levels of sulphur fertilization. Crop Res., 42 (1, 2 \& 3): 10-14.

Singh, S. and Singh, S. K. 2016. Use of indigenous sources of sulphur in soils of eastern India for higher crops yield and quality: A Review. Agricultural Reviews, 37(2): 117-124.

Podlesna, A. and Pietrzak, G. C. 2008. Effects of fertilization with sulphur on quality of winter wheat: a case study of nitrogen deprivation. Sulphur Assimilation and Abiotic Stress in Plants, pp 355-365.

Marok, A. S. and Dev. G. 1980. Phosphorus and sulphur inter-relationship in wheat (Triticum aestivum). Journal of the Indian Society of Soil Science, 28(2): 184-188.

Randhawa, P. S. and Arora, C. L. 2000. Phosphorus-sulphur interaction effect on dry matter yield and nutrient uptake by wheat. Journal of the Indian Society of Soil Science, 48(3): 536-540.

Islam, M. N., Hoque, S. and Islam, A. 2006. Effect of $\mathrm{P} \times \mathrm{S}$ interactions on nutrient concentration and yield of wheat, rice and mungbean. Journal of the Indian Society of Soil Science, 54(1): 86-91.

Abdallah, A. A., Mohamed, A. I., El-Sikhry, E. M. and Ali, O. M. 2013. Effect of sulphur application on wheat production in calcareous soil under saline irrigation water conditions. Journal of Soil and Water Sciences, 1: 7-11.

\section{How to cite this article:}

Deen Dayal Bairwa, J. M. Modhvadia and Bhawani Singh Prajapat. 2020. Effect of Phosphorus and Sulphur Fertilization on Yield and Quality of Wheat (Triticum aestivum L.). Int.J.Curr.Microbiol.App.Sci. 9(04): 633-638. doi: https://doi.org/10.20546/ijcmas.2020.904.077 